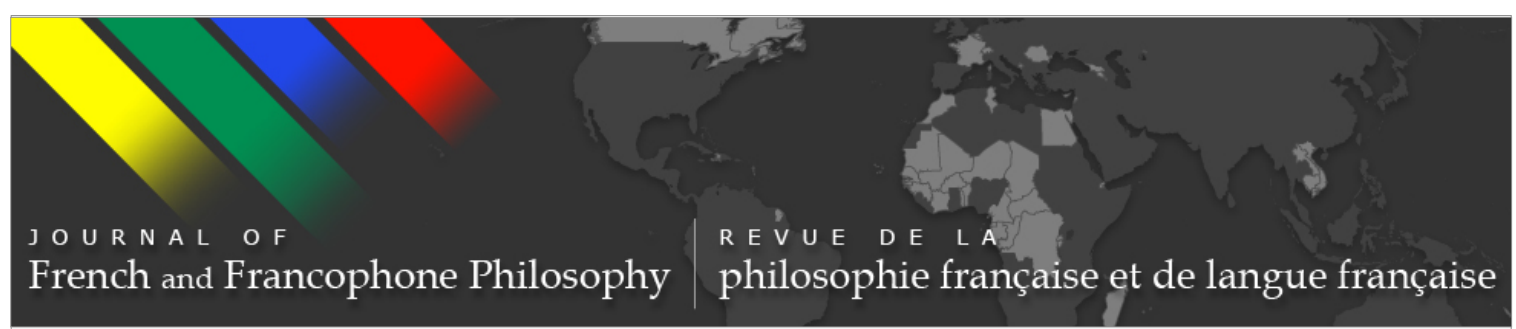

\title{
From Narcissus to Genius through the Work of Pleshette DeArmitt
}

Marygrace Hemme

Journal of French and Francophone Philosophy - Revue de la philosophie française et de langue française, Vol XXIII, No 2 (2015) pp 59-66

\author{
Vol XXIII, No 2 (2015) \\ ISSN 1936-6280 (print) \\ ISSN 2155-1162 (online) \\ DOI 10.5195/jffp.2015.701 \\ www.jffp.org
}

\section{(oc) BY-NG-ND}

This work is licensed under a Creative Commons Attribution-Noncommercial-No Derivative Works 3.0 United States License.

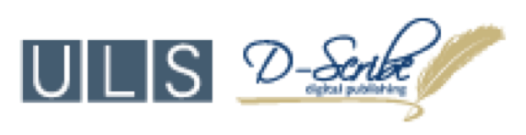

This journal is operated by the University Library System of the University of Pittsburgh as part of its D-Scribe Digital Publishing Program, and is co-sponsored by the University of Pittsburgh Press 


\section{From Narcissus to Genius through the Work of Pleshette DeArmitt}

Marygrace Hemme

The University of Memphis

\author{
in time of daffodils (who know \\ the goal of living is to grow) \\ forgetting why, remember how \\ in time of lilacs who proclaim \\ the aim of waking is to dream, \\ remember so (forgetting seem) \\ in time of roses (who amaze \\ our now and here with paradise) \\ forgetting if, remember yes \\ in time of all sweet things beyond \\ whatever mind may comprehend, \\ remember seek (forgetting find) \\ and in a mystery to be \\ (when time from time shall set us free) \\ forgetting me, remember me. \\ - E.E. Cummings, in time of daffodils
}

The daffodil, as you may know, has another name: Narcissus. According to the myth, when Narcissus dies he undergoes a metamorphosis. As he passes into the underworld he continues to stare at his reflection in the river Styx. When those who are going to bury him return to collect his body, they find a flower growing where his body should have been, its reflected image now replacing his. ${ }^{1}$ How does Narcissus become the daffodil, both metamorphosed and reflected? Perhaps it is through a love that echoes. Through my reading of the section of Pleshette Dearmitt's book The Right to

Journal of French and Francophone Philosophy | Revue de la philosophie française et de langue française Vol XXIII, No 2 (2015) | www.jffp.org | DOI 10.5195/jffp.2015.701 
Narcissism, entitled "Kristeva: the Rebirth of Narcissus," I hope to mirror this myth by showing the way in which DeArmitt's reading of Narcissus is reflected in Julia Kristeva's conception of genius.

One might say that a relationship with words, and the ability to form relationships through words and the ideas they implant in others, are at the center of the life of the scholar and the teacher, and for DeArmitt's work, words and relationships formed this center, not only in their role as a medium of communication, but as important concepts to be theorized themselves. In writing her book, DeArmitt took seriously the idea that by discussing just one word, narcissism, and re-narrating its relationship to other concepts, she could orchestrate its metamorphosis from being emblematic of problematic self-centeredness to showing that the other, especially the relationship to the mother for Kristeva, is central to the constitution and development of the self, as well as its flourishing. We might say that the enclosed bud of Narcissus blossomed through DeArmitt's words, under her pen. "The failure to articulate language as love reveals our inability to respond to narcissism" ${ }^{2}$ is DeArmitt's claim in the section of her book on Kristeva. According to her interpretation, all love is a form of narcissism, and it is love that makes possible language, meaning, and the self. Love is not just attachment, but is a passion which can both be represented and felt. According to DeArmitt's work, our problem today is not that we have too much narcissism, even though our "selfie" culture might make it appear that way. Rather, we do not have enough narcissism, and this is coupled with the inability to elaborate upon the meaning of narcissism or to put it into words that are connected to affect. This description of the problem echoes Kristeva's concern about the falling away of the semiotic, affective dimension of language from the symbolic, law-like aspect of language, which only together, through the signifying process, make meaning. DeArmitt's elaboration of narcissism in this section focuses on retracing the concept in psychoanalysis with, and through, Kristeva's thought. According to this account, psychoanalysis reveals that the speaking being is a wounded being whose speech wells up out of an ache for love and self-love is a primary identity organization which enables the emergence of the subject through psychic space. ${ }^{3}$

In order for individuation to occur, or for the subject to emerge, the infant must separate from the mother. This is a struggle, though, because the infant relies on the mother for care and does not yet see the mother as a separate being but as fused with the child in a state of plentitude. ${ }^{4}$ There is a bodily meaning structure in the mother's care that has a hold on the infant from which he or she must abject by rejecting the mother. ${ }^{5}$ In order to fully separate there must be a third term in the mother-child dyad, something other than the child which the mother desires. ${ }^{6}$ It is the separation that this "third" introduces that makes love between separate beings replace fusion 
into one being. Through discourse aimed at someone else the child begins to realize that there is a third party, ${ }^{7}$ which for Kristeva is the symbolic, or language, that makes space or absence possible. She sometimes calls this third the imaginary father, but it is important to note, according to DeArmitt, that the position of mother or father is not necessarily sexed, that these could just as easily be labeled as $X$ and $Y$, and that the figure of the third is actually a conglomeration of both parents. ${ }^{8}$ This is because there is no distinction between subject and object, so there is also no distinction between the parents yet.

Furthermore, because the child identifies with this figure, it is an ideal other, as the possibility of absence, of love, or of interdiction. ${ }^{9}$ In identification the subject-in-formation is transferred to the site of the other, to the place from which he or she is seen and heard. The mother's discourse with an other, her speech about her love for the child, and the stories she tells about the child, is the backdrop for the development of the mother's love for her child becoming manifest, making it possible for the child to begin to love himself or herself as a self. ${ }^{10}$ The emerging subject catches the words of others and repeats them, giving them back with his or her own voice. The primary identification, then, is mimicking sounds in the oral domain, "chewing, swallowing [and] nourishing oneself [. . . ] with words." ${ }^{11}$ The child loves himself or herself in learning and repeating language through which the other is symbolically taken in through rhythmic words, sounds, and signs. The speech of the other is a model or pattern with which the infant identifies repeatedly, and it is through identifying with the third, identifying and returning language, the forming subject becomes like the other, a subject him or herself who can use and recreate the other's language, allowing for self-reflection. ${ }^{12}$ In this account we can see that narcissism, self-love, and the self as self-reflective, can only come about through the relationship with, and words of, the other.

This individuation process occurs through transference, which Kristeva describes as having a metaphorical structure that "indicates a movement in which one thing is transported or carried over to the place of another, but it also implies an alteration or transformation. ${ }^{13}$ In other words, the metaphor is a metamorphosis and "what is at stake in transference is a metamorphosis in which the preverbal child-the infans-becomes capable of heterogeneous representations." ${ }^{14}$ I take these representations to be heterogeneous both in the sense that they are drawn from all of the senses and that they combine the two aspects of the signifying process, both the affective, semiotic level and the structured symbolic level. There is no fixed subject for Kristeva, but rather a subject-in-process as a series of repeated transferences, making the psychic space opened up in identification a space of the imaginary, "where seeming is not opposed to being, but rather where seeming is being." 15 These representations become the core of self-identity.

Journal of French and Francophone Philosophy | Revue de la philosophie française et de langue française Vol XXIII, No 2 (2015) | http://www.jffp.org | DOI 10.5195/jffp.2015.701 
All love comes from self-love because it is a repetition of this metaphor, of this identification and transference. The first variant of identification, or its first repetition, occurs through idealization, the capacity to project one's “own ideal image (itself an imaginary construction based on the child's first and most influential identification with the father-mother conglomeration in personal prehistory) onto the beloved only to have it returned." ${ }^{16}$ The lover is transferred to the place of the loved one, where the " $\mathrm{I}$ " is "paradoxically both expanded and annihilated as other" ${ }^{17}$ in a sort of "nontime" which is both "instant and eternity" that "fulfills me [and] abolishes me." ${ }^{18}$ Love, as love, is a blending of identities in a reciprocal transformation, making it a metamorphosed and doubled Narcissus: the daffodil growing on the bank of the Styx.

This rehabilitation of self-love as love for and through the other is what DeArmitt claimed Kristeva undertook in her more recent works, and is illustrated especially in Kristeva's works on revolt, The Sense and Non-sense of Revolt and Intimate Revolt, as well as in the Female Genius trilogy, a series of intellectual biographies about the political theorist Hannah Arendt, the psychoanalyst Melanie Klein, and the writer Colette. ${ }^{19}$ Kristeva's conception of revolt concerns the non-time of love as the time of identification ${ }^{20}$ described above. Intimate revolt has two parts, first, the return to, or recollection of, this "timeless" affective, semiotic realm that is not integrated into consciousness, and secondly, the expression of it in language, which fully accomplishes the experience in time. Revolt is the double movement of the dissolution or destabilization of the subject and meaning in identification and the accomplishment of meaning in the dialectic of the semiotic and symbolic through the stabilization of the subject experienced in the repetition of the narcissistic structure as a link to an other ${ }^{21}$ through words. The self is restructured through this experience and comprehension of the signifying process; that of losing the self in the experience of semiotic timelessness, and then integrating the rupture in time caused by the semiotic into linear time through the construction of symbols.

This conception of revolt informed DeArmitt's interpretation of Kristeva's conclusion to the Female Genius trilogy, entitled "Is There a Feminine Genius," which she often taught in her seminars. In this work Kristeva emphasizes three characteristics her geniuses share: a profound attachment to the other, the identification of life and thought, and living and conceiving of time as rebirth. To more explicitly state the connection, in the introduction to the trilogy Kristeva states that "the work of a genius culminates in the birth of a subject," which is the same work at stake in the metaphor of Narcissus. DeArmitt connected the idea of birth to Colette's use of the image of éclosion, which also means hatching or blossoming. ${ }^{22}$ Though DeArmitt did not explain the connection between Narcissus and genius in either her lectures or in her book, I will graft together the ideas that flowered

Journal of French and Francophone Philosophy | Revue de la philosophie française et de langue française Vol XXIII, No 2 (2015) | http://www.jffp.org | DOI 10.5195/jffp.2015.701 
through the spoken words of her lectures, the written words in her book, and my own work, which has budded from this inquiry, to illustrate that the aspects of feminine genius elaborate upon the rehabilitation or rebirth of Narcissus, since each aspect is born out the relationship of identification it recreates. A rehabilitation of narcissism and a rehabilitation of genius reflect one another, leading to a reconceptualization of the self.

You may not know that the flowers of Narcissus have a tripartite structure and fitting with this biological description, there are three volumes on feminine genius. These works are love stories since they are based on identification in their content and in their form. On a cultural level, each of Kristeva's geniuses has established a metaphorical relation that repeats the narcissistic structure, which is returned to through revolt. Though each genius has a relation that reflects this form, for each the relationship manifests itself through a different register. For Arendt, the relation is between the actor and the spectator; for Klein it is between the analyst and the analysand; and for Colette it is between the writer and the reader. Narration, the sharing of words, is also central to each of these relationships, and this is illustrated in the points of intersection between her geniuses which Kristeva draws from their lives and works.

In the volume on Hannah Arendt, "who" someone is comes about in the relationship between the spectator or narrator and the actor who is narrated. There is a transference here, though, because the positions change - those who narrate are also narrated, leaving the action that is initiated by the actor incomplete until it is given meaning through another action, the narration by the spectator. In this movement we narrate each other, and through others we are also narrated, forming a web of human relationships that make the identity, or the singularity of who someone is, possible. For Melanie Klein, the psychoanalyst identifies with the child being analyzed, and through this is taken back to the experience of the process of her own self-construction. She is then able to elaborate on the experiences of the child, freeing up the child's own ability to form an imaginary space of representations and the ability to narrate him or herself. Colette's written work, through sensorial language, turns symbols into flesh, rekindling the affective dimension of language. This occurs because she writes her mother as a metaphor, or, to put it differently, she writes through identifying with her mother (and her mother's writing in their lifelong correspondence through letters, which she reads and rewrites). By using her mother as a metaphor for her style, a metamorphosis occurs; Colette becomes like her mother and sees from a mother's point of view, becoming both the reader and the writer.

The structure of the Female Genius texts is also one of identification which creates renewal or revolt. In the Hannah Arendt volume, Kristeva describes one of Arendt's works, a biography of Rahel Varnhagen, as a work of identification (even is Arendt herself would have denied this). Arendt does claim that her only purpose was to narrate Varnhagen's life "as she

Journal of French and Francophone Philosophy | Revue de la philosophie française et de langue française 
would have told it." ${ }^{23}$ From this statement we can see why Kristeva might conclude that this is a work of identification, since it seems that Arendt had to put herself into the place of Varnhagen to write in this way, making this "narrative [. . .] the mediator for this metamorphosis." ${ }^{24}$ Importantly, this is no ordinary biography, but a work that is "dense, out of the ordinary, and peppered with many details that Rahel had revealed in her letters and diaries that the author often repeats without citing them as such" ${ }^{25}$ which Arendt intermixes with her own philosophical and personal reflections. At times it is difficult to determine whose voice is speaking in the text, and often the reader is able to forget, for pages, that the book being read is a biography and not an essay on social and political philosophy. Kristeva claims that the writing the life of Rahel was a fertile process that underlies Arendt's later work. We might imagine Kristeva's approach to writing the trilogy as an echo of Narcissus, since it seems she internalized a pattern of narration from Arendt's work in order to write this series of biographies. These works are also autobiographies that show the formation of the trajectory of Kristeva's thought, since she writes her theory by repeating the words of these women but endows them with her own thought by reforming their words through her own voice. We can now say that these works are of the genus, or better, the genius, of Narcissus.

DeArmitt's lectures, like her book, were close readings of others' texts that mapped the way a concept, a word, appeared, reappeared, and disappeared in the context of the work. She often explained the word's etymology and its use in the texts of other authors to create a fertile background in which to plot the relationship of this term to other concepts within the text at hand. She often used her own words, stories from her life and experiences, to illustrate difficult concepts, adding topsoil to the flower bed of meaning.

Nourished by DeArmitt's lectures in the graduate seminar she taught on the concept of the feminine in twentieth century Continental Philosophy, I became interested not only in her narration and re-narration of the concept of the feminine, but also in the way in which narration as a practice and as a concept itself is connected to femininity, subjectivity, metaphor and rebirth in the work of Kristeva. My dissertation project was born out of this inquiry. DeArmitt told me that "sometimes professors are inspired by the interests of their students," and I was delighted when she later taught a seminar on the connection between narration and the development and redefinition of the self in the work of Kristeva, Adrianna Cavarero and Judith Butler. DeArmitt's practice of passionately narrating and re-narrating these concepts inspired my interest in narration, which she reflected back to me, always deepening my inquiry, always budding new connections and thoughts. In her own words "one finds [narcissism] again in the object (where it is reflected)." ${ }^{26}$ Pleshette DeArmitt's words planted the bulb of the 
Narcissus in me, which even when its flower's season has passed is nourished by the soil that surrounds it. Although its blossoming is reflected in the river Styx, it survives the recurrences of winter, perpetually reblossoming.

${ }^{1}$ Ovid, Metamorphoses, trans. Allen Mandelbaum (New York: Harvest, 1993), 97.

2 Pleshette DeArmitt, The Right to Narcissism (New York: Fordham University Press, 2014), 56.

3 DeArmitt, The Right to Narcissism, 57.

${ }^{4}$ DeArmitt, The Right to Narcissism, 64.

${ }^{5}$ DeArmitt, The Right to Narcissism, 66.

${ }^{6}$ DeArmitt, The Right to Narcissism, 67.

${ }^{7}$ DeArmitt, The Right to Narcissism, 68.

8 DeArmitt, The Right to Narcissism, 69-70.

9 DeArmitt, The Right to Narcissism, 71

${ }^{10}$ DeArmitt, The Right to Narcissism, 72.

11 Julia Kristeva, Tales of Love, trans. Leon S. Roudiez (New York: Columbia University Press, 1987), 26.

12 DeArmitt, The Right to Narcissism, 74.

13 DeArmitt, The Right to Narcissism, 75.

${ }^{14}$ DeArmitt, The Right to Narcissism, 76.

${ }^{15}$ DeArmitt, The Right to Narcissism, 79.

${ }^{16}$ DeArmitt, The Right to Narcissism, 82.

17 Ibid.

${ }^{18}$ Kristeva, Tales of Love, 6.

${ }^{19}$ DeArmitt, The Right to Narcissism, 54.

20 Julia Kristeva, Intimate Revolt, trans. Jeanine Herman (New York: Columbia University Press, 2002), 21.

${ }^{21}$ Stacy Keltner, Kristeva: Thresholds (Malden, MA: Polity Press, 2011), 88.

22 DeArmitt, The Right to Narcissism, 67.

23 Hannah Arendt, Rahel Varnhagen: The Life of a Jewess, ed. Liliane Weissberg, trans. Richard and Clara Winston (Baltimore: Johns Hopkins University Press, 1997), 81.

${ }^{24}$ Arendt, Rahel Varnhagen, 69. 
66 From Narcissus to Genius through the Work of Pleshette DeArmitt

25 Julia Kristeva, Hannah Arendt, trans. Ross Guberman (New York: Columbia Univeristy Press, 2001), 49.

${ }^{26}$ Kristeva, Tales of Love, 22.

Journal of French and Francophone Philosophy | Revue de la philosophie française et de langue française Vol XXIII, No 2 (2015) | http://www.jffp.org | DOI 10.5195/jffp.2015.701 